\title{
MATHEMATICAL MODELLING LOW-FREQUENCY DYNAMICS OF FLOW CONTROLLER AT VARIOUS AMPLITUDES OF HARMONIC DISTURBANCE
}

Institute of Technical Mechanics of the National Academy of Sciences of Ukraine and the State Space Agency of Ukraine,15, Leshko-Popel Str., Dnepr, Ukraine, 49005, e-mail: dolmrut@gmail.com

A primary problem of mathematical modelling the low-frequency dynamic processes into a flow controller of a liquid rocket engine (LRE) is the construction of its linear mathematical model. This model forms a part of the LRE mathematical model as a whole and is used to analyze the LRE low-frequency dynamics and the longitudinal stability of a liquid rocket. The work objective is to develop a methodic approach to the construction of a linear mathematical model of the LRE flow controller at various (considerable) values of amplitudes of harmonic pressure fluctuations at its input. This approach consists of a numerical determination of equivalent (constructed on the first amplitudes of oscillation of a harmonic analysis) frequency characteristics of the flow controller using a nonlinear model with various amplitudes of pressure at the flow controller inlet; the formation of the equations of the linear model with the coefficients depending on nonlinear relations of hydraulic losses in pressure in cavities of the flow controller, and the dependence of the dry friction force on displacements of a slide valve; the determination of values of these coefficients from correlation of the frequency characteristics derived from linear and linear models of the low-frequency dynamics of a hydraulic system including the flow controller. Based on the methodic approach proposed, the frequency characteristics (the gain coefficient of the flow controller on pressure and input impedance of the flow controller) of the standard flow direct-action controller are determined. The results obtained can be used to analyze the LRE low-frequency dynamics and to assure the longitudinal stability of liquid rockets.

Keynords liquid rocket engine, direct-action flow controller, mathematical modeling, low-frequency dynamics, nonlinear relations, force of dry friction, gain coefficients, hydraulic input impedance inlet.

1. Shevyakov A. A., Kalnin V. M., Naumenkova M. V., Dyatlov V. G. Theory of Automatic Control of Rocket Engines. M.: Mashinostroenie, 1978. 288 p.

2. Glikman B. F. Automatic Control of Liquid Rocket Engines. M.: Mashinostroenie, 1974. 396 p.

3. Belyaev Ye. N., Chvanov V. K., Chervakov V. V. Mathematical Modelling an Operational Process of Liquid Rocket Engines. M.: MAI, 1999. 228 p.

4. Belyaev Ye. N., Chervakov V. V. Mathematical Modelling Liquid Rocket Engines. M.: MAI - PRINT, 2009. $280 \mathrm{p}$.

5. Lebedinsky Ye. V., Zaytsev B. V., Sobolev A. A. Multi-level mathematical modelling a flow controller for liquid rocket engine. Site GNTs FGUP "Tsentr Keldysha". 2011. P. 10

6. Belyaev Ye. N., Kolomentsev A. I., Nasimento L. B., Nazarov V. P. Effects of design parameters of a flow controller on its static and dynamic characteristics. Vestnik SibGAU. 2014. No 1(53). P. $109-113$.

7. Pylypenko V. V., Dovgotko N. I., Nikolaev A. D., Dolgopolov S. I., Khoryak N. V., Serenko V. A. Theoretical determination of dynamic loads ( longitudinal vibration accelerations) on structure of RS-20 liquid missile in its active flight trajectory. Tekhnicheskaya Mekhanika. 2000. No 1. P. 3 - 18.

8. Natanzon M. S. Longitudinal Self-Oscillation of Liquid Rocket. M.: Mashinostroenie, 1977. 208 p.

9. Netushil A. V., Baltrushevich A. V., Burlyaev V. V., Kuzin R. Ye., Aleksandrovsky N. M. Theory of Automatic Control: Nonlinear Systems, Control under Random Effects. M.: Vysshaya Shkola, 1983. 432 p.

10. Pylypenko M. V. Development of mathematical model of independent pneumatic suspension for driver's seat of vehicle with direct connection of vibration-isolation module. Tekhnicheskaya Tekhnika. 2008. No 1. P. $38-49$.

11. Besekersky V. A., Popov Ye. P. Theory of Systems for Automatic Controlling. M.: Nauka, 1972. 708 p.

12. Novogranov B. N. Calculations of Frequency Characteristics of Nonlinear Automatic Systems. M.: Mashinostroenie, $1986.200 \mathrm{p}$. 